\title{
The Antibacterial Action of Lactoperoxidase
}

\author{
THE NATURE OF THE BACTERIAL INHIBITOR
}

\author{
By D. McC. HOGG AND G. R. JAGO \\ Russell Grimwade School of Biochemistry, University of Melbourne, Parkville, Vic. 3052, Australia, and \\ Commonwealth Scientific and Industrial Research Organization Division of Dairy Research, Melbourne, \\ Vic. 3190, Australia
}

(Received 20 October 1969)

\begin{abstract}
Lactoperoxidase (EC 1.11.1.7), an enzyme present in various mammalian glands and in their secretions, catalyses the oxidation of thiocyanate by hydrogen peroxide to form a compound that inhibits the growth, oxygen uptake and acid production of certain bacteria. This compound was found to be too unstable to isolate in pure form, but its properties in dilute aqueous solution were studied with a view to establishing its identity. At thiocyanate concentrations of approximately $1 \mathrm{~mm}$, formation of the inhibitor, which took place by a nonstoicheiometric reaction, was maximal when an approximately equimolar amount of hydrogen peroxide was added. Excess of hydrogen peroxide oxidized the inhibitor to sulphate and cyanate. The inhibitor displayed a polarographic reduction wave of which the half-wave potential was pH-dependent. Studies of the variation of the polarographic half-wave potential and of the u.v. extinction with $\mathrm{pH}$ indicated that the inhibitor existed in an acid-base equilibrium $\left(\mathrm{p} K_{a} 5.1 \pm 0.1\right)$. The inhibitor decomposed by a mechanism involving $\mathrm{H}^{+}$ions and thiocyanate, the kinetics varying according to whether the inhibitor was in its acidic or basic form. From these studies it was concluded that the inhibitor was either cyanosulphurous acid $\left(\mathrm{HO}_{2} \mathrm{SCN}\right)$ or cyanosulphuric acid $\left(\mathrm{HO}_{3} \mathrm{SCN}\right)$.
\end{abstract}

The involvement of $L P^{*}$ in inhibition of bacterial growth was first suggested by Hanssen (1924) and was ultimately demonstrated by Wright \& Tramer (1958). Hydrogen peroxide (Jago \& Morrison, 1962) and thiocyanate (Reiter, Pickering, Oram \& Pope, 1963b) were shown also to be involved in the inhibition. This form of bacterial inhibition was first recognized as a hazard in the manufacture of cultured dairy products from normal cow's milk, which contains relatively large amounts of LP and thiocyanate. It has been suggested that the presence of LP in mammary, salivary, lacrimal and harderian glands may constitute a naturally occurring defence mechanism in the body to inhibit bacterial proliferation (Klebanoff \& Luebke, 1965; Morrison \& Allen, 1966; Slowey, Eidelman \& Klebanoff, 1968).

It appeared probable that inhibition by this system resulted from the ability of LP to catalyse the oxidation of thiocyanate by hydrogen peroxide, the active inhibitor being an oxidation product of thiocyanate. Excess of hydrogen peroxide abolished the inhibition, indicating that the inhibitor was an intermediate in the oxidation reaction and not a terminal oxidation product (Reiter, Pickering \& Oram 1963a, 1964).

* Abbreviation: LP, lactoperoxidase (EC 1.11.1.7).
Formation of the inhibitor was accompanied by an increase in extinction at $235 \mathrm{~nm}$, which decreased on the addition of excess of hydrogen peroxide (Reiter et al. 1963a, 1964). The substance responsible for this extinction change was reported by Oram \& Reiter (1966b) not to be inhibitory and to be more stable than the inhibitor. These workers investigated several known products of the chemical oxidation of thiocyanate by hydrogen peroxide, and found that, of these, only sulphur dicyanide caused inhibition. From the similarities in properties between the inhibitor and sulphur dicyanide, they concluded that the two substances were closely related, if not identical. The relationship between the substance absorbing at $235 \mathrm{~nm}$ and the inhibitor or sulphur dicyanide was considered to be obscure, although it seemed likely that they were structurally related. Other studies have been made to clarify the mode of action of the inhibitor (Clem \& Klebanoff, 1966; Klebanoff, Clem \& Luebke, 1966; Mickelson, 1966; Oram \& Reiter, 1966a; Steele \& Morrison, 1969), but none of these was concerned with its identification.

In this investigation, a study was made of the LP-catalysed oxidation of thiocyanate by hydrogen peroxide, and of various properties of the inhibitor 
to obtain further information as to the chemical identity of the inhibitor and to clarify its relationship to the substance absorbing at $235 \mathrm{~nm}$ and to sulphur dicyanide.

\section{MATERIALS AND METHODS}

Lactoperoxidase. Whey was prepared by the addition of rennet extract to fresh unpasteurized skim milk in the ratio $1: 3000(\mathrm{v} / \mathrm{v})$. The mixture was incubated at $38-40^{\circ} \mathrm{C}$ to facilitate syneresis of the curd particles. The whey was separated by gravity filtration (Whatman no. 1 paper) and the $\mathrm{pH}$ of the filtrate was adjusted to 8.0 with $10 \mathrm{M}-\mathrm{NaOH}$. The temperature of the whey filtrate was adjusted to $25^{\circ} \mathrm{C}$ and $\left(\mathrm{NH}_{4}\right)_{2} \mathrm{SO}_{4}$ was added to give $50 \%$ saturation $(313 \mathrm{~g} / \mathrm{l})$ with constant mechanical stirring. The $\mathrm{pH}$ was maintained at 8.0 by the addition of $10 \mathrm{M}-\mathrm{NaOH}$. After standing for $18-24 \mathrm{~h}$ at $5^{\circ} \mathrm{C}$, the precipitated protein was removed by gravity filtration (Whatman no. 1 paper). The temperature of the filtrate was raised to $25^{\circ} \mathrm{C}$ and further $\left(\mathrm{NH}_{4}\right)_{2} \mathrm{SO}_{4}$ was added to give $60 \%$ saturation $(66 \mathrm{~g} / \mathrm{l})$ with constant stirring, the $\mathrm{pH}$ being maintained at 8.0. After the $\left(\mathrm{NH}_{4}\right)_{2} \mathrm{SO}_{4}$ had completely dissolved, the mixture was allowed to stand for 10-15 min. During this time, the LP slowly precipitated to form large waxy aggregates. The enzyme was collected by filtration through glass wool with slight suction. After washing with a $60 \%$ saturated $\left(\mathrm{NH}_{4}\right)_{2} \mathrm{SO}_{4}$ solution, the enzyme was eluted by immersing the glass wool in a small volume of water. The LP solution was dialysed against $0.01 \mathrm{~m}$ sodium acetate buffer, pH5.7, and the enzyme was further purified by chromatography on CM-cellulose by using the method of Morrison \& Hultquist (1963). The purified enzyme was dialysed against $0.05 \mathrm{M}$-sodium phosphate

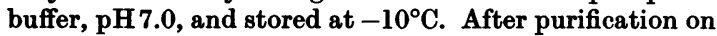
CM-cellulose, the LP had an $E_{412} / E_{280}$ ratio varying from 0.59 to 0.95 depending on the fraction. The concentration of LP was determined by measuring the extinction at $412 \mathrm{~nm}$ and applying the molar extinction coefficient $\left(1.1 \times 10^{5} \mathrm{M}^{-1} \mathrm{~cm}^{-1}\right)$ determined by Morrison, Hamilton \& Stotz (1957).

LP activity was removed from solution by ultrafiltration through a Millipore membrane filter, type VM or VF, immediately after completion of the enzymic reaction. Complete removal of LP activity was demonstrated by the inability of the filtrate to catalyse the oxidation of either guaiacol or thiocyanate by hydrogen peroxide or to bring about inhibition in the presence of thiocyanate.

Chemicals. Standard KSCN solution was prepared from B.D.H. Analytical Reagent by the method of Kolthoff \& Lingane (1935). Hydrogen peroxide solutions (usually $18 \mathrm{~mm}$ ) were prepared freshly by dilution of $30 \%$ sta bilized $\mathrm{H}_{2} \mathrm{O}_{2}$ (Univar A. R.) and standardized against $\mathrm{KMnO}_{4}$ (Kolthoff \& Sandell, 1952). Sulphur dicyanide was prepared and purified by the method of Kitching, Smith \& Wilson (1962), and was resublimed in vacuo immediately before use. Thiocyanogen was prepared in dioxan (dried and redistilled over sodium) according to the method of Seel \& Müller (1955).

Bacteria. Streptococcus cremoris 972 was maintained by daily subculture in skim milk $(10 \%$ solution of milk solids, $w / v)$, and was grown in quantity in a broth containing tryptone (Difco), 30 $\mathrm{g} / \mathrm{l}$, yeast extract (Difco), $10 \mathrm{~g} / \mathrm{l}$, lactose, $5 \mathrm{~g} / 1, \mathrm{~K}_{2} \mathrm{HPO}_{4}, 5 \mathrm{~g} / \mathrm{l}$, and Lab Lemco beef extract (Oxoid), $2 \mathrm{~g} / \mathrm{l}$ in tap water at $\mathrm{pH}$ 6.5. The medium was filtered through coarse filter paper (Postlip crinkled grey) and autoclaved at a pressure of $15 \mathrm{lb} / \mathrm{in}^{2}$ for $10 \mathrm{~min}$. The broth was inoculated from the skim milk cultures, and incubated at $30^{\circ} \mathrm{C}$ for $16 \mathrm{~h}$. The cells were collected by centrifugation at $30000 \mathrm{~g}$ for $20 \mathrm{~min}$ at $4^{\circ} \mathrm{C}$, washed twice with $0.9 \% \mathrm{NaCl}$, and resuspended in $0.9 \% \mathrm{NaCl}$ or in the required buffer solution.

\section{Methods for studying the inhibition}

Manometric estimation of oxygen uptake. Oxygen uptake was measured with conventional Warburg flasks in a gas phase of air at $30^{\circ} \mathrm{C}$. Incubation mixtures consisted of washed bacterial cells, LP and KSCN at the required concentration (or, alternatively, preformed inhibitor) and glucose ( $27 \mathrm{mM}$ ) in buffer (usually $27 \mathrm{mM}$-sodium phosphate, pH 7.0). The glucose (in a volume of $0.3 \mathrm{ml}$ ) was placed in the sidearm and the flask was preincubated for $10 \mathrm{~min}$ at $30^{\circ} \mathrm{C}$ before tipping. The centre well contained $0.2 \mathrm{ml}$ of $10 \%(\mathrm{w} / \mathrm{v}) \mathrm{KOH}$ and a folded square of filter paper.

Amperometric estimation of oxygen uptake. Oxygen uptake was estimated amperometrically by using a vibrating platinum electrode. The oxygen concentration was recorded at $-0.6 \mathrm{~V}$ with respect to a $\mathrm{Ag} / \mathrm{AgCl}$ reference electrode. Inhibitor solution $(1.2 \mathrm{ml}$, preincubated at $30^{\circ} \mathrm{C}$ ) and $0.2 \mathrm{ml}$ of bacterial cell suspension (prepared and stored at $0^{\circ} \mathrm{C}$ to prevent $\mathrm{H}_{2} \mathrm{O}_{2}$ formation) were incubated at $30^{\circ} \mathrm{C}$ for $1 \mathrm{~min}$, then $0.1 \mathrm{ml}$ of $\mathrm{M}$-glucose was added. All reagents were prepared in $0.1 \mathrm{M}$-potassium phosphate buffer, $\mathrm{pH}$ 7.0.

Acid production in a recording $\mathrm{pH}-$ stat. A Radiometer $\mathrm{pH}$-stat was used which consisted of the following components: Recorder, SBR2c; Autoburette, ABU1b; pH meter, 28b; Titrator, TTT1la. The inhibitor was prepared by mixing $1.5 \mathrm{ml}$ of $0.9 \% \mathrm{NaCl}, 1.4 \mathrm{ml}$ of $0.8 \mathrm{mM}$ KSCN, $0.1 \mathrm{ml}$ of LP in $0.01 \mathrm{M}$-sodium phosphate buffer, $\mathrm{pH} 7.0$, and the required volume of $18 \mathrm{mM} \cdot \mathrm{H}_{2} \mathrm{O}_{2}$. A volume $(1 \mathrm{ml})$ of this solution (preincubated at $30^{\circ} \mathrm{C}$ ) was placed in the electrode chamber with $0.2 \mathrm{ml}$ of cell suspension in $0.9 \% \mathrm{NaCl}$ (stored at $0^{\circ} \mathrm{C}$ ) and incubated at $30^{\circ} \mathrm{C}$ until a steady endogenous rate of acid production was achieved (1-2 min). Then $0.3 \mathrm{ml}$ of $\mathrm{M}$-glucose was added and the acid produced was titrated with $0.01 \mathrm{M}-\mathrm{NaOH}$.

\section{Methods for studying the oxidation reaction}

Spectrophotometric studies at $235 \mathrm{~nm}$. The oxidation of $\mathrm{SCN}^{-}$by $\mathrm{LP}$ and $\mathrm{H}_{2} \mathrm{O}_{2}$ was accompanied by a change in extinction at about $235 \mathrm{~nm}$, which could be used to estimate the extent of $\mathrm{SCN}^{-}$oxidation. To a $3 \mathrm{ml}$ cuvette was added $1.5 \mathrm{ml}$ of buffer $(0.05 \mathrm{M}$-sodium phosphate, $\mathrm{pH}$ 7.0, unless otherwise specified), $1.4 \mathrm{ml}$ of KSCN (usually $0.8 \mathrm{mM}$ ), $0.1 \mathrm{ml}$ of LP (usually $0.04-0.07 \mu \mathrm{M}$ in the appropriate buffer) and the required volume of $18 \mathrm{~mm}$ $\mathrm{H}_{2} \mathrm{O}_{2}$. The $E_{235}$ was measured against a blank containing no $\mathrm{SCN}^{-}$or $\mathrm{H}_{2} \mathrm{O}_{2}$.

Spectral determinations. Spectra were obtained with a Cary Recording Spectrophotometer, model 14.

Polarographic studies. It was found that the inhibitor displayed a polarographic wave with a half-wave potential that was $\mathrm{pH}$-dependent, ranging from $-0.2 \mathrm{~V}$ at $\mathrm{pH} 4$ and below to $-0.4 \mathrm{~V}$ at $\mathrm{pH} 7$, when measured against a $\mathrm{Ag} / \mathrm{AgCl}$ 
reference electrode. A Metrohm Polarecord type E261 polarograph was used. The reaction mixture contained $0.1 \mathrm{M}-\mathrm{KCl}$ as the carrier electrolyte, $5 \mathrm{~mm}$-sodium phosphate and/or $2.5 \mathrm{~mm}$-sodium citrate at the required $\mathrm{pH}$, and $\mathrm{LP}, \mathrm{KSCN}$ and $\mathrm{H}_{2} \mathrm{O}_{2}$ at the required concentrations in a total volume of $10 \mathrm{ml}$. Oxygen was removed by purging with nitrogen. Quantitative measurements were performed at $-0.7 \mathrm{~V}$ versus the $\mathrm{Ag} / \mathrm{AgCl}$ electrode. At this potential, the diffusion current was reached at all $\mathrm{pH}$ values throughout the range studied.

In the polarographic kinetic studies of the decomposition of the inhibitor, the inhibitor solution contained $0.37 \mathrm{~mm}-\mathrm{KSCN}, 0.37 \mathrm{~mm}-\mathrm{H}_{2} \mathrm{O}_{2}$ and $43 \mathrm{~nm}-\mathrm{LP}$ in $5 \mathrm{~mm}$ sodium phosphate-2.5mm-sodium citrate at pH7.0. After flushing with nitrogen, an additional $0.25 \mathrm{ml}$ of a solution containing the required concentrations of KSCN and $\mathrm{HCl}$ or $\mathrm{NaOH}$ (previously flushed with nitrogen) was added and mixed by bubbling with nitrogen. The initial rate of decrease of the diffusion current was then measured. The $\mathrm{pH}$ of the solution was measured at the completion of the polarographic determination.

Chemical analysis of acidified inhibitor solutions. The inhibitor was found to be unstable to acid treatment and to heating, and this interfered with direct chemical determinations of the inhibitor, thiocyanate and other oxidation products. Chemical analyses were therefore carried out by treating the oxidation mixture with acid, then estimating the products after acid hydrolysis as thiocyanate, cyanide, sulphate and ammonia. Acid hydrolysis was carried out by adding $1.0 \mathrm{ml}$ of $\mathrm{M}-\mathrm{HClO}_{4}$ to $10 \mathrm{ml}$ of inhibitor solution. The solution was left at room temperature for $15 \mathrm{~min}$, then neutralized with $\mathrm{M}-\mathrm{NaOH}$ to $\mathrm{pH}$ 7. This procedure ensured complete decomposition of the inhibitor to thiocyanate, cyanide, sulphate and cyanate, the last-named undergoing partial hydrolysis to ammonia and bicarbonate. Thiocyanate and cyanide were estimated by the method of Bruce, Howard \& Hanzal (1955). Sulphate was estimated by the method of Letonoff \& Reinhold (1936). Cyanate and ammonia were estimated together by making the solution $0.5 \mathrm{M}$ with respect to $\mathrm{HCl}$ (to hydrolyse the cyanate completely) and then by estimating the ammonia by the method of Johnson, Driedger \& Marko (1964).

\section{RESULTS}

Stoicheiometry of formation and oxidation of the inhibitor. As shown in Fig. 1, maximum inhibition of both oxygen uptake and acid production by Streptococcus cremoris 972 was obtained when hydrogen peroxide and thiocyanate were present in equimolar amounts. In the absence of hydrogen peroxide, or at hydrogen peroxide/thiocyanate ratios greater than 2, inhibition was slight or absent.

The increase in $E_{235}$ on the addition of hydrogen peroxide to thiocyanate and $\mathrm{LP}$ at $\mathrm{pH} 7.0$ was maximal at a hydrogen peroxide/thiocyanate ratio of 1 (Fig. 2a), and the addition of further hydrogen peroxide, caused the $E_{235}$ to decrease until the hydrogen peroxide/thiocyanate ratio was 4 . The hydrogen peroxide/thiocyanate ratio for maximum

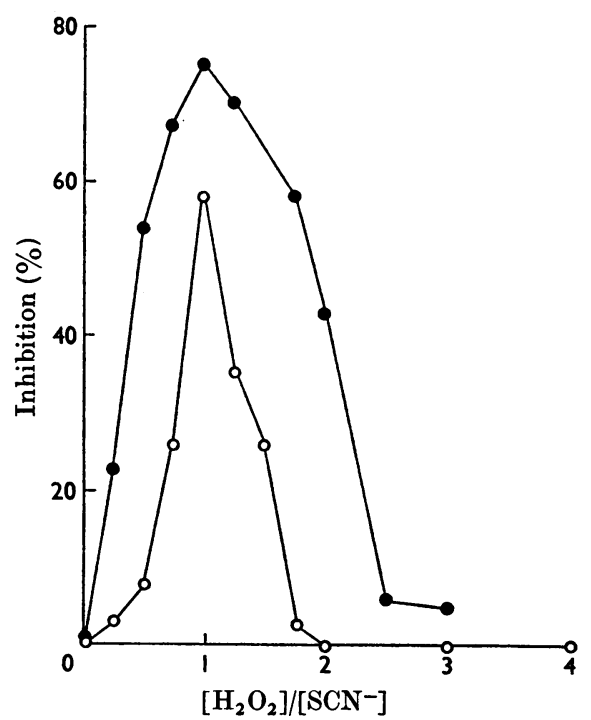

Fig. 1. Effect of hydrogen peroxide/thiocyanate ratio on inhibition of oxygen uptake and acid production by $S$. cremoris 972 in the presence of LP. Inhibition of oxygen uptake (๑) was determined amperometrically with an incubation mixture containing $0.30 \mathrm{mM}-\mathrm{KSCN}, \mathrm{H}_{2} \mathrm{O}_{2}$ as indicated, $34 \mathrm{nM}-\mathrm{LP}, 67 \mathrm{~mm}$-glucose and bacterial cells in 0.1 m-potassium phosphate buffer, $\mathrm{pH} 7.0$, at $30^{\circ} \mathrm{C}$. Inhibition of acid production (O) was determined with an incubation mixture containing $0.25 \mathrm{~mm}-\mathrm{KSCN}$, $\mathrm{H}_{2} \mathrm{O}_{2}$ as indicated, $29 \mathrm{nM}$-LP, $0.2 \mathrm{M}$-glucose and bacterial cells in $72 \mathrm{~mm}-\mathrm{NaCl}-0.22 \mathrm{~mm}$-sodium phosphate buffer,

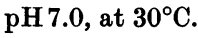

$E_{235}$ at $\mathrm{pH} 7.0$ remained approx. 1 over thiocyanate concentrations in the range $0.19-1.49 \mathrm{~mm}$.

When the concentration of the inhibitor was estimated polarographically, the maximum diffusion current was obtained at a hydrogen peroxide/ thiocyanate ratio between 1.0 and 1.25 (Fig. 3). Above a ratio of 2.0, the diffusion current could not be determined because of interference from unchanged hydrogen peroxide.

Chemical analysis of the acidified reaction mixture at different stages of the oxidation reaction accounted for all the original thiocyanate as thiocyanate, cyanide, sulphate and cyanate (estimated as ammonia). The utilization of thiocyanate and the formation of ammonia and sulphate occurred steadily throughout the oxidation reaction, but the formation of cyanide was maximal at a hydrogen peroxide/thiocyanate ratio of 1 (Table 1).

The requirement for equimolar amounts of thiocyanate and hydrogen peroxide for maximum inhibition of bacterial oxygen uptake and acid production, for maximal increase in $\boldsymbol{E}_{235}$, for maximal polarographic diffusion current and for 
maximal liberation of cyanide on acidification, suggested that the same substance was responsible for all these phenomena. On the basis of this assumption, against which no evidence was obtained in this investigation, the substance responsible for each of these phenomena will henceforth be described as the inhibitor.

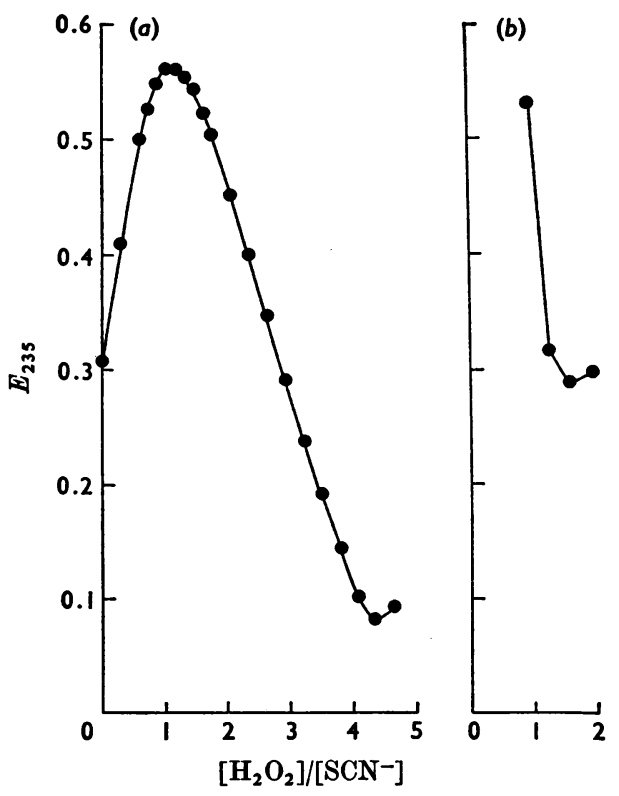

Fig. 2. Effect of hydrogen peroxide/thiocyanate ratio on $E_{235}$. (a) The reaction mixture contained $0.37 \mathrm{mM}-\mathrm{KSCN}$ and 68nM-LP in $27 \mathrm{~mm}$-sodium phosphate buffer, pH 7.0, at room temperature. Small increments of $18 \mathrm{mM}-\mathrm{H}_{2} \mathrm{O}_{2}$ were added. The $E_{235}$ values measured after each addition of $\mathrm{H}_{2} \mathrm{O}_{2}$ were corrected for changes in the volume of the solution. (b) LP was removed by Millipore filtration after $\mathrm{H}_{2} \mathrm{O}_{2}$ had been added in an amount equimolar to the $\mathrm{SCN}^{-}$.
The stoicheiometric significance of the hydrogen peroxide/thiocyanate ratio of 1 for maximal formation of the inhibitor is doubtful. As shown in Figs. 2 and 3, the amount of the inhibitor formed per unit amount of hydrogen peroxide added decreased as the hydrogen peroxide/thiocyanate ratio approached 1 , indicating utilization of the hydrogen peroxide in another reaction. (Complete

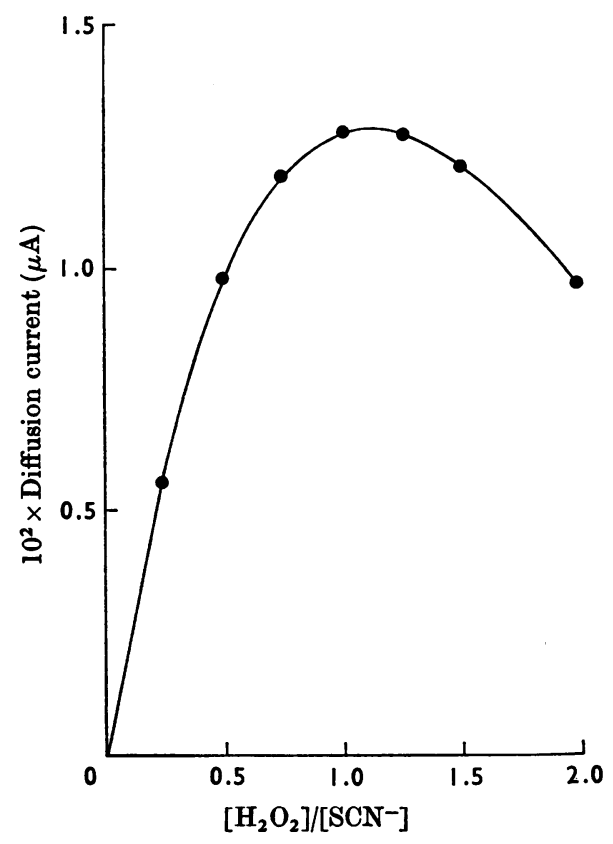

Fig. 3. Effect of hydrogen peroxide/thiocyanate ratio on the height of the polarographic wave of the LP-thiocyanate-hydrogen peroxide system. The reaction mixture contained $0.37 \mathrm{mM}-\mathrm{KSCN}, \mathrm{H}_{2} \mathrm{O}_{2}$ as indicated and $43 \mathrm{~nm}-\mathrm{LP}$ in $0.1 \mathrm{M}-\mathrm{KCl}-48 \mathrm{~mm}$-sodium phosphate buffer, pH 7.0, at $30^{\circ} \mathrm{C}$.

Table 1. Products of acidified reaction mixtures containing LP, thiocyanate and various amounts of hydrogen peroxide

Before acidification, the reaction mixture contained $0.37 \mathrm{mM}-\mathrm{KSCN}, 68 \mathrm{nM}-\mathrm{LP}$ and $\mathrm{H}_{2} \mathrm{O}_{2}$ as indicated in 27 mM-sodium phosphate buffer, $\mathrm{pH}$ 7.0.

\begin{tabular}{ccccccc} 
& \multicolumn{5}{c}{ Products $(\mu \mathrm{mol} / \mathrm{ml}$ of original reaction mixture $)$} \\
\cline { 2 - 6 } $\mathrm{H}_{2} \mathrm{O}_{2} / \mathrm{SCN}^{-}$ratio & Thiocyanate & Cyanide & Ammonia & Sulphate & Total C+N & Total S \\
0 & 0.37 & 0 & 0 & 0 & 0.37 & 0.37 \\
0.5 & 0.31 & 0.06 & 0.02 & 0.07 & 0.39 & 0.38 \\
1 & 0.28 & 0.08 & 0.04 & 0.10 & 0.40 & 0.38 \\
2 & 0.18 & 0.06 & 0.13 & 0.21 & 0.37 & 0.39 \\
3 & 0.10 & 0.03 & 0.24 & 0.28 & 0.37 & 0.38 \\
4 & 0.09 & 0 & 0.28 & 0.27 & 0.37 & 0.36 \\
5 & 0.10 & 0 & 0.28 & 0.24 & 0.38 & 0.34
\end{tabular}


utilization of added hydrogen peroxide in the reaction mixture was confirmed by the absence of a polarographic wave for hydrogen peroxide.) Further evidence for the occurrence of a second reaction during inhibitor formation was demonstrated by the lack of an isosbestic point during the reaction when hydrogen peroxide was added to thiocyanate in amounts up to that required to give a hydrogen peroxide/thiocyanate ratio of 1 .

The second reaction utilizing hydrogen peroxide appeared to be the oxidation of the inhibitor by hydrogen peroxide. Two kinetically distinct mechanisms were found for this reaction. When LP was removed from the inhibitor solution by Millipore filtration, the oxidation of the inhibitor, as determined by the decrease in $E_{235}$, was first order with respect to both hydrogen peroxide and to inhibitor. In the presence of LP, the oxidation was first order with respect to the inhibitor and approximately zero order with respect to hydrogen peroxide, except at low hydrogen peroxide concentrations when hydrogen peroxide became limiting and at high hydrogen peroxide concentrations when inhibition of the reaction by hydrogen peroxide occurred. The kinetics of the first reaction are characteristic of a direct chemical oxidation of the inhibitor by hydrogen peroxide, and those of the second reaction are characteristic of a peroxidasecatalysed oxidation. The reaction in the presence of $L P$ was much more rapid than in its absence, the actual rate being dependent on the LP concentration. However, both these reactions were considerably slower than the oxidation of thiocyanate to form the inhibitor.

The stoicheiometry of the oxidation of the inhibitor by hydrogen peroxide was also dependent on the presence or absence of LP. As shown in Fig. 2(a) complete oxidation in the presence of LP occurred at a hydrogen peroxide/thiocyanate ratio of approx. 4. However, if LP was removed after formation of the inhibitor from equimolar amounts of hydrogen peroxide and thiocyanate, oxidation

Table 2. Effect of $\mathrm{pH}$ of the inhibitor on the inhibition of oxygen uptake by $\mathrm{S}$. cremoris 972

Oxygen uptake was measured manometrically. The incubation mixture contained $0.20 \mathrm{mM}-\mathrm{KSCN}, 73 \mathrm{nM}-\mathrm{LP}$, $27 \mathrm{mM}$-glucose and bacterial cells in either $22 \mathrm{mM}$-sodium phosphate buffer, pH 7.0, 25 mm-sodium phosphate$10 \mathrm{~mm}$-sodium citrate buffer, pH5.5 or $20 \mathrm{mM}$-sodium phosphate-12mm-sodium citrate buffer, $\mathrm{pH} 4.5$, as indicated.

$\begin{array}{cc}\text { pH } & \text { Inhibition (\%) } \\ \mathbf{7 . 0} & \mathbf{5 0} \\ \mathbf{5 . 5} & \mathbf{8 0} \\ \mathbf{4 . 5} & \mathbf{8 4}\end{array}$

of the inhibitor ceased at a hydrogen peroxide/ thiocyanate ratio of 1.3 (Fig. $2 b$ ).

Effect of $\mathrm{pH}$ on inhibitor formation. The percentage inhibition of oxygen uptake by $S$. cremoris 972 in the presence of the inhibitor was found to be pH-dependent, inhibition being greater at lower $\mathrm{pH}$ values (Table 2). (The normal rate of oxygen uptake at $\mathrm{pH} 4.5$ was approx. $70 \%$ of the normal rate at $\mathrm{pH}$ 7.0.) The u.v. spectrum of the inhibition was also influenced by $\mathrm{pH}$ (Fig. 4). An extinction maximum at $218 \mathrm{~nm}$ was obtained at $\mathrm{pH} 7.0$ but no extinction maximum was obtained above $200 \mathrm{~nm}$ at $\mathrm{pH} 4.2$ or 3.3. When the $E_{235}$ of the inhibitor was measured during its formation, it was found to decrease below pH4.8 (Fig. 5). No variation in the spectra of thiocyanate or LP was observed over this pH range.

When the inhibitor was formed at $\mathrm{pH} 7.0$ and the solution was adjusted to $\mathrm{pH} 4.5$ before the addition of bacterial cells, the percentage inhibition was the same as that obtained when the inhibitor was formed at pH4.5 (Table 3). Similarly, when the inhibitor was tested at $\mathrm{pH} 7.0$, the percentage inhibition was the same regardless of whether the

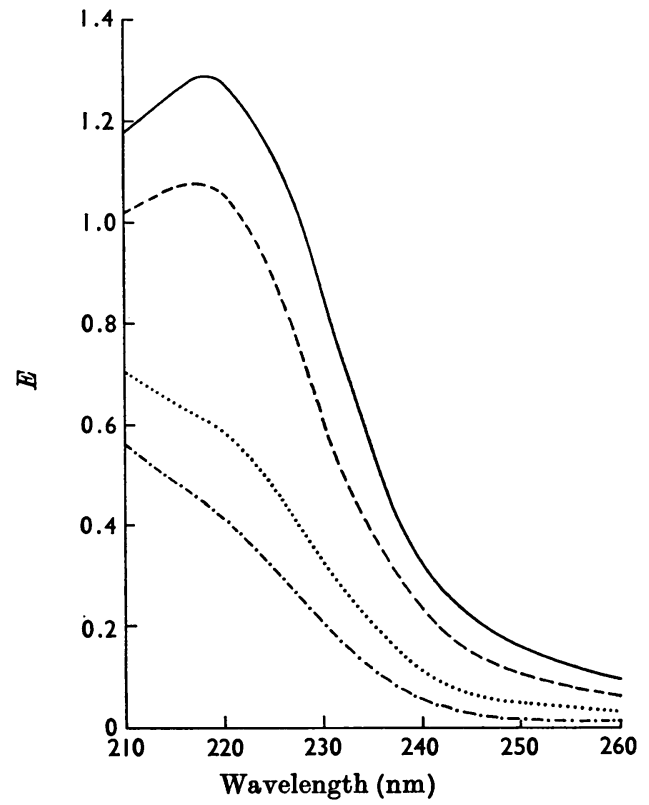

Fig. 4. Effect of pH on the u.v. spectrum of the inhibitor. The reaction mixture contained $0.37 \mathrm{~mm}-\mathrm{KSCN}, 0.37 \mathrm{mM}$ $\mathrm{H}_{2} \mathrm{O}_{2}$ and $68 \mathrm{~nm}-\mathrm{LP}$ in the appropriate buffer at $20^{\circ} \mathrm{C}$. $\longrightarrow$ pH7.2 (27 mM-sodium phosphate); -- - , pH5.5 (30 mM-sodium phosphate-11 mM-sodium citrate); $\cdots \cdots$, pH4.2 (23 mM-sodium phosphate-15 mM-sodium citrate); -.-.-.-., pH3.3 (14 mM-sodium phosphate-19mmsodium citrate). 


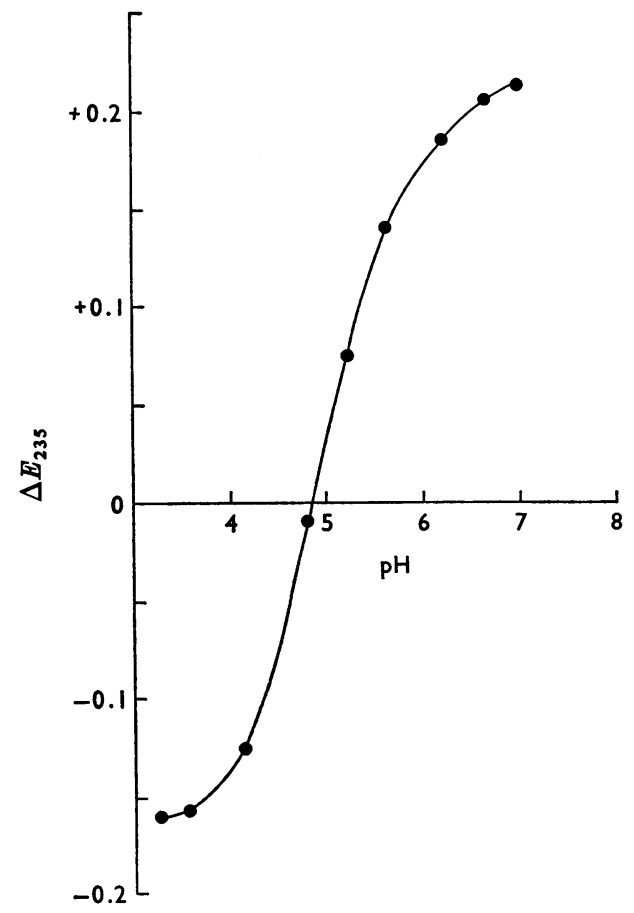

Fig. 5. Effect of $\mathrm{pH}$ on the change in $E_{235}$ on addition of $\mathrm{H}_{2} \mathrm{O}_{2}$ to $\mathrm{LP}$ and thiocyanate. The reaction mixture contained $0.37 \mathrm{~mm}-\mathrm{KSCN}, 0.37 \mathrm{~mm}-\mathrm{H}_{2} \mathrm{O}_{2}$ and $46 \mathrm{nM}-\mathrm{LP}$ in $10 \mathrm{~mm}$-sodium phosphate- $5 \mathrm{~mm}$-sodium citrate buffer at the $\mathrm{pH}$ indicated at $30^{\circ} \mathrm{C}$.

inhibitor had been formed at $\mathrm{pH} 7.0$ or at $\mathrm{pH} 4.5$. The u.v. extinctions of these solutions of the inhibitor were found similarly to depend on the adjusted $\mathrm{pH}$ of the solution, and not on the $\mathrm{pH}$ at which the inhibitor was formed. This change in $E_{235}$ with pH is shown in Table 4 .

These results indicated that the inhibitor existed in more than one form and that the forms were in a state of rapid $\mathrm{pH}$-dependent equilibrium. Certain oxidation products of thiocyanate (e.g., thiocyanogen $\left[(\mathrm{SCN})_{2}\right]$ and hypothiocyanous acid (HOSCN)) are believed to exist in a pH-dependent equilibrium involving thiocyanate (Bjerrum \& Kirschner, 1918; Kerr, 1966). To test whether thiocyanate was involved in the equilibrium, or, alternatively, whether the equilibrium was a simple acid-base equilibrium, the sigmoidal variation of $E_{235}$ with $\mathrm{pH}$ was examined at several thiocyanate concentrations. From these results, $\log \left[\left(E-E_{\min .}\right) /\left(E_{\max .}-E\right)\right]$ was plotted against $\mathrm{pH}$ [where $E_{\max }$ is the $E_{235}$ value when all the ionizable compound is in the form with the higher extinction (i.e. in this case the form existing at
Table 3. Effect of varying the $\mathrm{pH}$ after formation of the inhibitor on the inhibition of oxygen uptake by S. cremoris 972

$\mathrm{HCl}(0.1 \mathrm{ml})$, at a concentration predetermined to give a final $\mathrm{pH}$ of 4.5 , was added to $3.0 \mathrm{ml}$ of formed inhibitor in phosphate-citrate buffer at $\mathrm{pH}$ 7.0. A control was prepared in which $\mathrm{HCl}$ was added before formation of the inhibitor by the addition of $\mathrm{H}_{2} \mathrm{O}_{2}$. Analogous solutions, prepared at $\mathrm{pH} 4.5$, were adjusted to $\mathrm{pH} 7.0$ by the addition of $0.1 \mathrm{ml}$ of $\mathrm{NaOH}$ solution. Oxygen uptake was measured manometrically. The incubation mixture contained $0.20 \mathrm{~mm}-\mathrm{KSCN}, 0.16 \mathrm{~mm}-\mathrm{H}_{2} \mathrm{O}_{2}, 36 \mathrm{~nm}-\mathrm{LP}, 27 \mathrm{~mm}$-glucose and bacterial cells in $22 \mathrm{~mm}$-sodium phosphate- $11 \mathrm{~mm}$ sodium citrate buffer at the $\mathrm{pH}$ indicated.

$\mathrm{pH}$ of inhibitor
formation
7.0
4.5
4.5
7.0

$\begin{array}{cc}\mathrm{pH} \text { of assay } & \text { Inhibition }(\%) \\ 7.0 & 43 \\ 7.0 & 49 \\ 4.5 & 83 \\ 4.5 & 92\end{array}$

Table 4. Effect of varying the $\mathrm{pH}$ after formation of the inhibitor on the $\boldsymbol{E}_{235}$ value of the inhibitor

The inhibitor solutions were prepared as in Table 2. The reaction mixture contained $0.37 \mathrm{~mm}-\mathrm{KSCN}, 0.37 \mathrm{~mm}$ $\mathrm{H}_{2} \mathrm{O}_{2}$ and $68 \mathrm{~nm}$-LP in $27 \mathrm{~mm}$-sodium phosphate- $13 \mathrm{~mm}$ sodium citrate buffer at the $\mathrm{pH}$ indicated.

$\begin{array}{ccc}\begin{array}{c}\mathrm{pH} \text { of inhibitor } \\ \text { formation }\end{array} & \begin{array}{c}\mathrm{pH} \text { of } \\ \boldsymbol{E}_{235} \text { measurement }\end{array} & \boldsymbol{E}_{235} \\ 7.0 & 7.0 & 0.512 \\ 4.5 & 7.0 & 0.525 \\ 4.5 & 4.5 & 0.282 \\ 7.0 & 4.5 & 0.264\end{array}$

pH 7.0 and above), $E_{\min .}$ is the $E_{235}$ value when all the ionizable compound is in the form with the lower extinction, and $E$ is the $E_{235}$ value when a mixture of both forms is present].

For a simple acid-base equilibrium:

$$
\log \left(\frac{E-E_{\min } .}{E_{\max .}-E}\right)=\mathrm{pH}-\mathrm{p} K_{a}
$$

Hence the plot should be a straight line of unit slope intercepting the abscissa at $\mathrm{p} K_{a}$, and independent of thiocyanate concentration. This was found to be the case, as indicated by the results in Table 5 , and the $\mathrm{p} K_{a}$ was found to be $5.1 \pm 0.1$.

Further evidence supporting the existence of such an equilibrium was obtained from variations in the polarographic half-wave potential of the inhibitor. The slope of the polarographic wave for a typical reduction of the dropping-mercury electrode is described by the equation: 


$$
E=E_{\frac{1}{2}}-\frac{R T}{\alpha F} \ln \left(\frac{i}{i_{\mathrm{d}}-i}\right)
$$

where $E(\mathrm{~V})$ is the potential at the electrode, $i(\mathrm{~A})$ is the current carried at this potential, $i_{\mathrm{d}}(\mathrm{A})$ is the diffusion current, $E_{\frac{1}{2}}(\mathrm{~V})$ is the half-wave potential, $T\left({ }^{\circ} \mathrm{K}\right)$ is the absolute temperature, $\boldsymbol{R}$ is the universal gas constant, $F$ is the Faraday and $\alpha$ is a constant.

At $30^{\circ} \mathrm{C}$, the temperature at which the present studies were made:

$$
E=E_{\frac{1}{2}}-\frac{0.060}{\alpha} \log \left(\frac{i}{i_{\mathrm{d}}-i}\right)
$$

$E_{\frac{1}{2}}$ and $\alpha$ can thus be determined by plotting $\log \left[i /\left(i_{\mathrm{d}}-i\right)\right]$ against $E$. This was done for solutions of the inhibitor in the $\mathrm{pH}$ range 3.2-9.3. These solutions were prepared by two methods: (i) the inhibitor was prepared at the $\mathrm{pH}$ used in the test; (ii) the inhibitor was prepared at pH 7.0, then the $\mathrm{pH}$ of the solution was adjusted to the required value by the addition of sodium hydroxide or hydrochloric acid.

The half-wave potential was in both cases found to be pH-dependent. As shown in Fig. 6, $E_{\frac{1}{2}}$ shifted linearly to a less negative potential as the $\mathrm{pH}$ decreased from 8 to about 5. Between pH5 and 4, its value remained constant, and below $\mathrm{pH4}$, it appeared to revert to a more negative potential. However, because of decomposition of the inhibitor the results below pH4 were not reliable. This

Table 5. Determination of $\mathrm{p} K_{a}$ for inhibitor at various thiocyanate concentrations

Inhibitor solution was prepared containing $0.37 \mathrm{~mm}$ $\mathrm{KSCN}, 0.37 \mathrm{~mm}-\mathrm{H}_{2} \mathrm{O}_{2}$ and $46 \mathrm{~nm}-\mathrm{LP}$ in $5.3 \mathrm{~mm}$-sodium phosphate-2.5mm-sodium citrate buffer, pH7.0. To $48 \mathrm{ml}$ of inhibitor solution was added $2.2 \mathrm{ml}$ of $\mathrm{KSCN}$ at the required concentration. Portions $(3 \mathrm{ml})$ were preincubated at $30^{\circ} \mathrm{C}$, then $0.1 \mathrm{ml}$ of $\mathrm{HCl}$ or $\mathrm{NaOH}$ was added to give the required $\mathrm{pH}$. The $E_{235}$ of the solution was measured at $30^{\circ} \mathrm{C}$ against a blank prepared identically except that $\mathrm{SCN}^{-}$and $\mathrm{H}_{2} \mathrm{O}_{2}$ were omitted. The $\mathrm{p} K_{a}$ values were determined by plotting $\log \left[\left(E-E_{\min }\right) /\right.$ $\left.\left(E_{\max }-E\right)\right]$ against $\mathrm{pH}$ (see the Results section), and the slopes of these plots were measured. The $\mathrm{SCN}^{-}$concentrations quoted represent the final concentrations in the reaction mixture of $\mathrm{SCN}^{-}$added after inhibitor formation and do not take into account any unchanged $\mathrm{SCN}^{-}$remaining in the inhibitor solution.

$\begin{array}{ccc}\begin{array}{c}\text { Concn. of SCN- } \\ \text { (mM) }\end{array} & \mathrm{p} K_{a} & \text { Slope } \\ 0 & 5.1_{0} & 1.04 \\ 0.35 & 5.0_{2} & 1.05 \\ 0.70 & 5.0_{8} & 0.98 \\ 1.05 & 5.2_{0} & 1.00\end{array}$

pattern of variation of $E_{\frac{1}{2}}$ with $\mathrm{pH}$ is indicative of an electrode mechanism of the type:

$$
\begin{aligned}
& \mathrm{HA} \rightleftharpoons \mathrm{H}^{+}+\mathrm{A}^{-} \\
& \mathrm{HA}+n e \rightarrow \mathrm{B}
\end{aligned}
$$

where equilibrium (1) is rapid compared with reaction (2) and where $\mathrm{p} K_{a}$ for equilibrium (1) is given by the point of inflexion on the curve. This was estimated to be 5.2 from both sets of results. The value was in good agreement with that obtained spectrophotometrically. $E_{\frac{1}{z}}$ was found to be independent of thiocyanate concentration, thus confirming that thiocyanate was not involved in the equilibrium.

The value of $\alpha$ was also found to be pH-dependent, having a maximum value of 0.6 at about $\mathrm{pH} 5$ and decreasing approximately linearly to 0.4 at pH3.5 or 0.1 at $\mathrm{pH}$. The reason for the variation of $\alpha$ with $\mathrm{pH}$ was not established.

Stability of the inhibitor. The inhibitor was found to be unstable to heating. Inhibitor solutions were prepared containing $0.37 \mathrm{~mm}$-thiocyanate, $0.37 \mathrm{~mm}$ hydrogen peroxide and 46nM-LP in $0.1 \mathrm{M}$-potassium phosphate buffer, pH 7.0. LP was removed by Millipore filtration and the solutions were incubated

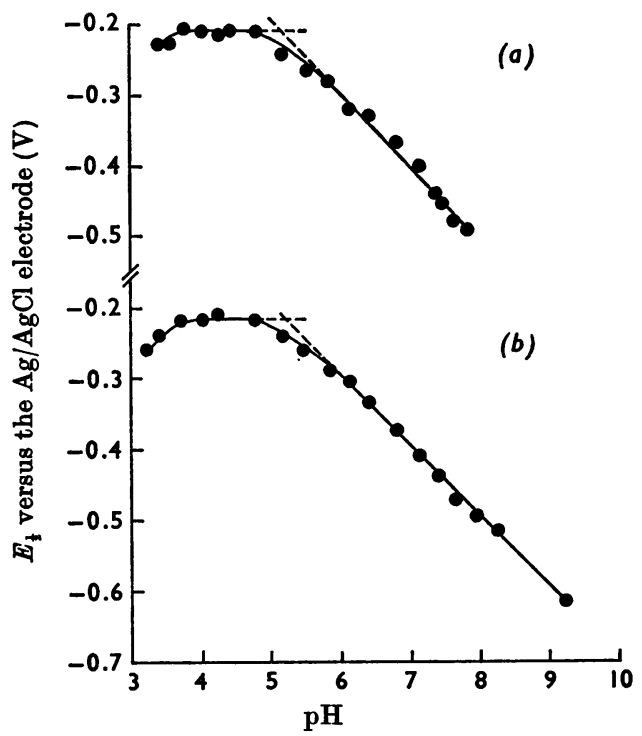

Fig. 6. Effect of $\mathrm{pH}$ on the polarographic half-wave potential $\left(E_{t}\right)$ of the inhibitor. The reaction mixture contained $0.37 \mathrm{~mm}-\mathrm{KSCN}, 0.37 \mathrm{mM}-\mathrm{H}_{2} \mathrm{O}_{2}$ and $43 \mathrm{nM}-\mathrm{LP}$ in $0.1 \mathrm{M}-\mathrm{KCl}-5 \mathrm{~mm}$-sodium phosphate-2.5mm-sodium citrate buffer at $30^{\circ} \mathrm{C}$. (a) Solutions of the inhibitor were prepared at the $\mathrm{pH}$ indicated. (b) Solutions of the inhibitor were prepared at $\mathrm{pH} 7.0$ and adjusted to the $\mathrm{pH}$ indicated by the addition of $\mathrm{NaOH}$ or $\mathrm{HCl}$. 
for $20 \mathrm{~min}$ at various temperatures, then tested amperometrically for their ability to inhibit oxygen uptake by $S$. cremoris 972. Inhibitor solutions incubated at temperatures between 0 and $40^{\circ} \mathrm{C}$ inhibited oxygen uptake by approx. $80 \%$, but all inhibitory activity was lost in solutions heated to $60^{\circ} \mathrm{C}$ or above. (If LP was not removed, solutions heated to $60^{\circ} \mathrm{C}$ retained their inhibitory activity, presumably as a result of reoxidation by LP and bacterial hydrogen peroxide of thiocyanate remaining after decomposition of the inhibitor.)

At low temperatures, the inhibitor was stable for several days. Inhibitor solutions were prepared containing $0.37 \mathrm{~mm}$-thiocyanate, $0.31 \mathrm{~mm}$-hydrogen peroxide and 68nM-LP in $27 \mathrm{~mm}$-sodium phosphate buffer, pH 7.0. LP was removed by Millipore filtration and the solutions were left for 3 days at $4^{\circ} \mathrm{C}$ or at room temperature (approx. $20^{\circ} \mathrm{C}$ ). These solutions (diluted 1 in 1.9 and tested manometrically) gave comparable degrees of inhibition when compared with a freshly prepared inhibitor solution. The observed stability of the inhibitor at neutral $\mathrm{pH}$ is in contrast with the observation of Oram \& Reiter (1966b).

Effect of buffer type on inhibitor formation. Most of the experiments concerned with the formation of the inhibitor were performed in the presence of phosphate. To establish whether phosphate was a component of the inhibitory system, the inhibitor was formed in acetate ( $\mathrm{pH}$ 4.5) and tris-maleate (pH 7.0) buffers. Although the oxygen uptake by the cells was much lower than usual, presumably as a result of phosphate depletion, inhibition could be demonstrated in both cases. (Complete absence of phosphate in this system could not be obtained because of the presence of endogenous phosphate in the cells.) The u.v. spectra of the inhibitor formed in acetate ( $\mathrm{pH}$ 4.5) and in triethanolamine ( $\mathrm{pH}$ 7.0) buffers were identical with those of the inhibitor formed in phosphate-citrate and phosphate buffers at the respective $\mathrm{pH}$ values. Hence specific buffer ions do not appear to be involved in either the inhibition or the extinction changes during the oxidation reaction.

Kinetics of the decomposition of the inhibitor. The decomposition of the inhibitor was found to be dependent on both $\mathrm{H}^{+}$ions and thiocyanate, and the kinetics differed according to whether the reaction was carried out at a $\mathrm{pH}$ value above or below the $\mathrm{p} K_{a}$ of the inhibitor. At $\mathrm{pH}$ values above the $\mathrm{p} K_{a}$ of the inhibitor (pH 5.6-7.2), the reaction was of order $\frac{1}{2}$ with respect to $\mathrm{H}^{+}$ions and thiocyanate and of order $1 \frac{1}{2}$ with respect to the inhibitor. Below the $\mathrm{p} K_{a}$ of the inhibitor (pH 3.2-4.4), the reaction was first order with respect to $\mathrm{H}^{+}$ions, thiocyanate and the inhibitor. Studies on the variation of rate with thiocyanate concentration indicated that, in the inhibitor solution, at least half of the thiocyanate initially added to form the inhibitor remained as such at the completion of inhibitor formation, being either unused or regenerated during the reaction. The decomposition of the inhibitor at all the $\mathrm{pH}$ values examined was zero order with respect to $L P$, buffer and potassium chloride, indicating that none of these substances was involved in the rate-determining step of the decomposition.

Attempts to prepare concentrated solutions of the inhibitor. It was found that when the inhibitor was prepared with high concentrations of thiocyanate and equimolar amounts of hydrogen peroxide in $27 \mathrm{~mm}$-sodium phosphate buffer, $\mathrm{pH} 7.0$, the relative yield of the inhibitor decreased, as was indicated both spectrophotometrically and polarographically. Spectrophotometric studies indicated that at concentrations of thiocyanate above $7 \mathrm{~mm}$, even the absolute yield of inhibitor became less with increasing thiocyanate concentration. At such concentrations of thiocyanate, relatively high concentrations of LP $(0.215 \mu \mathrm{M})$ were required for the maximal yield of the inhibitor.

Attempts to isolate the inhibitor. The techniques available for isolating the inhibitor were restricted by the failure to produce it in high concentrations and by its limited stability. Paper chromatography in a range of solvents showed thiocyanate to be the only sulphur-containing compound detected on spraying with azide-iodide (Chargaff, Levine \& Green, 1948) or chloroplatinic acid-iodide (Toennies \& Kolb, 1951). Acidification of the paper before spraying to decompose the inhibitor to thiocyanate did not improve the result. The inhibitor presumably decomposed on chromatography, particularly when acid or alkaline solvents were used. Oram \& Reiter (1966b) had found previously that thiocyanate was the only radioactive compound detected by radioautography of chromatograms of thio $\left[{ }^{14} \mathrm{C}\right] \mathrm{cy}$ anate oxidized by various molar ratios of hydrogen peroxide in the presence of LP.

Attempts to separate the inhibitor by solvent extraction (carbon tetrachloride, carbon disulphide), ion-exchange (Dowex 1, X8) or gel filtration (Sephadex G-25) were all unsuccessful.

Attempts to prepare metal complexes of the inhibitor. Thiocyanate is known to form coloured complexes with $\mathrm{Fe}^{3+}$ (Lewin \& Wagner, 1953), $\mathrm{Co}^{2+}$ (Uri, 1947) and $\mathrm{Ni}^{2+}$ (Uri, 1947). To test whether the inhibitor reacted similarly, solutions of the inhibitor were prepared in acetate buffer at pH6.0 $(0.37 \mathrm{~mm}$ thiocyanate) and metal ion solutions (final concentration $13 \mathrm{mM}$ or $67 \mathrm{~mm}$ ) were added. The metal ions tested were $\mathrm{Co}^{2+}, \mathrm{Cu}^{2+}, \mathrm{Fe}^{3+}, \mathrm{Cd}^{2+}, \mathrm{Mg}^{2+}$, $\mathrm{Mn}^{2+}, \mathrm{Ni}^{2+}, \mathrm{Ba}^{2+}, \mathrm{Zn}^{2+}, \mathrm{Pb}^{2+}, \mathrm{Cr}^{3+}$ and $\mathrm{Ca}^{2+}$. $\mathrm{As}$ the addition of solvents such as acetone or ethanol intensifies the colour of the cobalt-thiocyanate complex (Uri, 1947), the addition of acetone, 


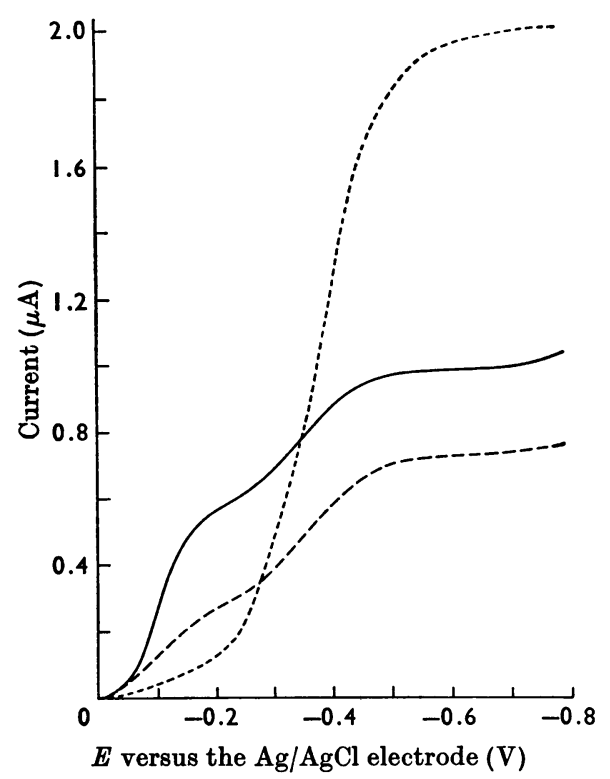

Fig. 7. Polarograms of the inhibitor, sulphur dicyanide and thiocyanogen. The inhibitor solution contained $0.37 \mathrm{~mm}-\mathrm{KSCN}, 0.37 \mathrm{~mm}-\mathrm{H}_{2} \mathrm{O}_{2}$ and $43 \mathrm{~nm}-\mathrm{LP}$ in $0.1 \mathrm{~m}-$ KCl-5 mM-sodium phosphate-2.5mm-sodium citrate buffer, pH 7.0. The sulphur dicyanide and thiocyanogen solutions were prepared by adding to $10 \mathrm{ml}$ of $0.1 \mathrm{M}-\mathrm{KCl}-$ 50 mM-sodium phosphate-25 mM-sodium citrate buffer, pH 7.0, $0.1 \mathrm{ml}$ of dioxan containing sulphur dicyanide or thiocyanogen to give a final $\mathrm{C}$ or $\mathrm{N}$ concentration of $0.4 \mathrm{~mm}$. All polarograms were recorded at $30^{\circ} \mathrm{C}$. $\ldots .$. , Inhibitor; - - - , sulphur dicyanide; - - , thiocyanogen.

dioxan or ethanol in concentrations up to $77 \%$ to the above solutions was examined. However, as indicated by spectral measurements in the range 300-700 nm, in no instance, either in the presence or the absence of an organic solvent, was there any indication of the formation of a complex between metal ions and the inhibitor.

Comparison with other oxidation products of thiocyanate. Sulphate, sulphite, cyanate, cyanide and ammonia, all of which have been demonstrated or postulated to be formed during the chemical oxidation of thiocyanate by hydrogen peroxide (Wilson \& Harris, 1961), showed no resemblance to the inhibitor in either inhibitory, spectroscopic or polarographic properties. Sulphur dicyanide, however, was inhibitory (in agreement with the observation of Oram \& Reiter, 1966b) and in addition displayed a polarographic wave resembling that of the inhibitor (Fig. 7), although the estimation of the half-wave potential of this wave was complicated by the presence of a second wave at a less negative potential. Such a polarographic pattern was displayed also by an aqueous solution of thiocyanogen (Fig. 7), although this substance was not found to be inhibitory.

\section{DISCUSSION}

In view of the inability to isolate the inhibitor and to identify it by direct chemical means, an indication of its identity can best be obtained from a consideration of its properties. It appears from studies of the stoicheiometry of its formation that the inhibitor is responsible for the increase in $E_{235}$. This contrasts with the reports of Reiter et al. (1964) and Oram \& Reiter (1966b) who claimed that the $235 \mathrm{~nm}$-absorbing substance was not inhibitory. Their failure to detect inhibition of acid production may have been due to the low hydrogen peroxide/ thiocyanate ratio (0.4) used in forming the inhibitor. While a significant increase in $\boldsymbol{E}_{\mathbf{2 3 5}}$ could be observed at this ratio (Fig. 2), inhibition of acid production was only $10 \%$ of the inhibition obtained with a hydrogen peroxide/thiocyanate ratio of 1 (Fig. 1).

It is apparent that the inhibitor is none of the established products of the chemical oxidation of thiocyanate by hydrogen peroxide. These include sulphate, sulphite, cyanate, cyanide and ammonia. Thiocyanogen, which is formed on oxidation of thiocyanate by halogens in non-aqueous solvents (Wood, 1946), is instantaneously decomposed in aqueous solution (Kerr, 1966). Sulphur dicyanide appeared both from this investigation and from the work of Oram \& Reiter (1966b) to be inhibitory. However, this is also unstable in aqueous solution under neutral or alkaline conditions. From the results of Kitching et al. (1962), the half-life of sulphur dicyanide in $27 \mathrm{~mm}$-phosphate buffer at pH6.7 and $0^{\circ} \mathrm{C}$ was calculated to be $11.3 \mathrm{~min}$, and it is thus too unstable to be the inhibitor. It may, however, upon decomposition under these conditions, give rise to the inhibitor. Evidence that it does was provided by the observation that an aqueous solution of sulphur dicyanide displayed a polarographic wave with a half-wave potential close to that of the inhibitor at pH 7.0. Hence it appeared that the inhibitor was not an established oxidation product of thiocyanate, and that it may be a new compound.

The chemical oxidation of thiocyanate by hydrogen peroxide was investigated by Wilson \& Harris (1961), who postulated, on the basis of kinetic studies, that above $\mathrm{pH} 4$ the oxidation occurred by the following mechanism:

$$
\begin{aligned}
\mathrm{SCN}^{-}+\mathrm{H}_{2} \mathrm{O}_{2} & \rightarrow \mathrm{HOSCN}+\mathrm{OH}^{-} \\
\mathrm{HOSCN}+\mathrm{H}_{2} \mathrm{O}_{2} & \rightarrow \mathrm{HOOSCN}+\mathrm{H}_{2} \mathrm{O} \\
\mathrm{HOOSCN}+\mathrm{H}_{2} \mathrm{O}_{2} & \rightarrow \mathrm{H}_{2} \mathrm{SO}_{3}+\mathrm{HOCN}
\end{aligned}
$$




$$
\begin{aligned}
& \mathrm{HOCN}+2 \mathrm{H}_{2} \mathrm{O} \rightarrow \mathrm{HCO}_{3}{ }^{-}+\mathrm{NH}_{4}{ }^{+} \\
& \mathrm{H}_{2} \mathrm{SO}_{3}+\mathrm{H}_{2} \mathrm{O}_{2} \rightarrow \mathrm{H}_{2} \mathrm{SO}_{4}+\mathrm{H}_{2} \mathrm{O}
\end{aligned}
$$

The species HOSCN, HOOSCN and $\mathrm{H}_{2} \mathrm{SO}_{3}$ were postulated as unstable intermediates and their existence in this reaction was not confirmed. On mechanistic grounds, the most likely structures expected for the compounds, HOSCN and HOOSCN, are respectively :

$$
\begin{aligned}
\mathrm{H}-\mathrm{O}-\mathrm{S}-\mathrm{C} \equiv \mathrm{N} & \text { (hypothiocyanous acid) } \\
\mathrm{O} & \| \\
\mathrm{H}-\mathrm{O}-\mathrm{S}-\mathrm{C} \equiv \mathrm{N} & \text { (cyanosulphurous acid) }
\end{aligned}
$$

HOSCN has been proposed in other reactions including the hydrolysis of thiocyanogen (Bjerrum \& Kirschner, 1918; Söderbäck, 1919; Lecher, Wittwer \& Speer, 1923; Kerr, 1966), the hydrolysis of sulphur dicyanide (Kitching et al. 1962) and the oxidation of thiocyanate by peroxomonosulphate (Smith \& Wilson, 1967). Cyanosulphurous acid was reported to have been prepared in liquid hydrogen cyanide by Jander, Grüttner \& Scholz (1947), who claimed that it was unstable in aqueous solution. It has also been postulated as an intermediate in the hydrolysis of thiocyanogen (Bjerrum \& Kirschner, 1918).

Cyanosulphuric acid

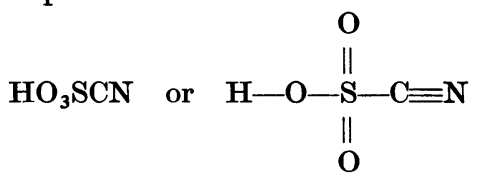

the next member in this series of oxyacids of thiocyanate, was also postulated as an intermediate in thiocyanogen hydrolysis (Bjerrum \& Kirschner, 1918; Söderbäck, 1919). Its formation during the chemical oxidation of thiocyanate by hydrogen peroxide is compatible with the results of Wilson \& Harris (1961), if reactions (5) and (7) in the above mechanism are replaced by the reactions :

$$
\begin{aligned}
& \mathrm{HO}_{2} \mathrm{SCN}+\mathrm{H}_{2} \mathrm{O}_{2} \rightarrow \mathrm{HO}_{3} \mathrm{SCN}+\mathrm{H}_{2} \mathrm{O} \\
& \mathrm{HO}_{3} \mathrm{SCN}+\mathrm{H}_{2} \mathrm{O}_{2} \rightarrow \mathrm{HOCN}+\mathrm{H}_{2} \mathrm{SO}_{4}
\end{aligned}
$$

It is reasonable to expect that enzymic oxidation of thiocyanate by hydrogen peroxide, which yields the same end-products as chemical oxidation, may occur via this series of oxyacids of thiocyanate, and that one of these may be sufficiently stable under mild conditions to be the inhibitor. However, as none of these compounds is known to have been prepared chemically in aqueous solution, direct comparison with the inhibitor is not possible.

It seems feasible that all these compounds would be able to fulfil the requirements of the inhibitor with respect to their existence in an acid-base equilibrium, their oxidation by excess of hydrogen peroxide and their ability to be reduced at a dropping-mercury electrode.

Mechanisms could be proposed for each of these compounds to account for the observed kinetics of decomposition of the inhibitor at low $\mathrm{pH}(3.2-4.4)$. At high pH (5.6-7.2) only the following mechanisms could be proposed for $\mathrm{HO}_{2} \mathrm{SCN}$ and $\mathrm{HO}_{3} \mathrm{SCN}$ :

(i) $\mathrm{O}_{2} \mathrm{SCN}^{-}+\mathrm{SCN}^{-}+\mathrm{H}^{+} \rightleftharpoons \mathrm{HSO}_{2}{ }^{-}+\mathrm{S}(\mathrm{CN})_{2}$ $\mathrm{O}_{2} \mathrm{SCN}^{-}+\mathrm{HSO}_{2}^{-}$or $\left.\mathrm{S}(\mathrm{CN})_{2}\right] \rightarrow$ Products

(ii) $\mathrm{O}_{3} \mathrm{SCN}^{-}+\mathrm{SCN}^{-}+\mathrm{H}^{+} \rightleftharpoons \mathrm{HSO}_{3}^{-}+\mathrm{S}(\mathrm{CN})_{2}$ $\mathrm{O}_{3} \mathrm{SCN}^{-}+\mathrm{HSO}_{3}^{-}$[or $\left.\mathrm{S}(\mathrm{CN})_{2}\right] \rightarrow$ Products

(iii) $\mathrm{O}_{3} \mathrm{SCN}^{-}+\mathrm{SCN}^{-}+\mathrm{H}^{+} \rightleftharpoons \mathrm{O}_{2} \mathrm{SCN}^{-}+\mathrm{HOSCN}$ $\mathrm{O}_{3} \mathrm{SCN}^{-}+\mathrm{O}_{2} \mathrm{SCN}^{-}$(or HOSCN) $\rightarrow$ Products

(iv) $\mathrm{O}_{3} \mathrm{SCN}^{-}+\mathrm{SCN}^{-}+\mathrm{H}^{+} \rightleftharpoons \mathrm{HO}_{2} \mathrm{SCN}+\mathrm{OSCN}^{-}$ $\mathrm{O}_{3} \mathrm{SCN}^{-}+\mathrm{HO}_{2} \mathrm{SCN}$ (or $\mathrm{OSCN}^{-}$) $\rightarrow$ Products

Evidence in support of mechanism (ii) was provided by the observation that bisulphite reacted extremely rapidly with the inhibitor at pH6, even too fast at the concentrations used to determine the kinetics of the reaction. An immediate decrease in $E_{235}$ on the addition of sulphite had been previously observed by Oram \& Reiter (1966b). Sulphur dicyanide appeared to react slowly with the inhibitor, as indicated spectrophotometrically, but this reaction could be accounted for by the thiocyanate produced as a result of the hydrolysis of sulphur dicyanide under neutral conditions (Kitching et al. 1962). The reaction between the species $\mathrm{HSO}_{2}{ }^{-}$and the inhibitor was not examined because the compound could not be prepared.

An additional factor operating in mechanisms involving sulphur dicyanide is the reaction of sulphur dicyanide with other nucleophiles in solution (for example, $\mathrm{OH}^{-}, \mathrm{HPO}_{4}{ }^{2-}$ ). However, it was calculated from the results of Kitching et al. (1962) that such reactions would occur at only about onehundredth the rate of the decomposition of the inhibitor and would not be significant under the conditions of the experiment.

Mechanisms (iii) and (iv) fit the observed kinetics if the species HOSCN and $\mathrm{O}_{2} \mathrm{SCN}^{-}$or $\mathrm{HO}_{2} \mathrm{SCN}$ and $\mathrm{OSCN}^{-}$are not rapidly interconvertible.

The inhibitor was not found to be formed during the chemical oxidation of thiocyanate by hydrogen peroxide and, in fact, its formation in this reaction in significant concentration would not be expected. The chemical oxidation of thiocyanate by hydrogen peroxide between pH4 and 12 is first order with respect to thiocyanate and hydrogen peroxide, and the rate constant at $29.8^{\circ} \mathrm{C}$ was found by Wilson \& Harris (1960) to be $(3.1 \pm 0.3) \times$ $10^{-2} \mathrm{M}^{-1} \mathrm{~min}^{-1}$. From kinetic studies of the oxida- 
tion of the inhibitor by hydrogen peroxide in the absence of LP, the second-order rate constant at $30^{\circ} \mathrm{C}$ was calculated to be $(1.5 \pm 0.2) \times 10^{3} \mathrm{M}^{-1} \mathrm{~min}^{-1}$. Hence oxidation of the inhibitor by hydrogen peroxide would occur far more rapidly than its formation in the absence of LP.

It appears unlikely that the inhibitor can be isolated or even obtained as a pure solution. As yet, the inhibitor has not been prepared free from thiocyanate and any attempt to concentrate solutions of the inhibitor would favour its decomposition, which at neutral $\mathrm{pH}$ is of order $1 \frac{1}{2}$ with respect to the inhibitor and of order $\frac{1}{2}$ with respect to thiocyanate. This is presumably a factor contributing to the decreased yield of the inhibitor at high thiocyanate concentration.

No satisfactory mechanism could be proposed if the inhibitor were assumed to be HOSCN, even if the reaction orders of $\frac{1}{3}$ or $\frac{2}{3}$ with respect to thiocyanate and hydrogen ion and orders of $1 \frac{1}{3}$ or $1 \frac{2}{3}$ with respect to the inhibitor were considered, these orders being possible within the range of experimental error.

Further evidence supporting the belief that the inhibitor is not HOSCN can be obtained from a study of the plot of $E_{235}$ versus $\left[\mathrm{H}_{2} \mathrm{O}_{2}\right]$ in Fig. 2, from which it is possible to calculate the concentrations of the inhibitor, thiocyanate and other oxidation products present in solutions of the inhibitor to which known amounts of thiocyanate and hydrogen peroxide have been added. It is first necessary to assume: (i) that the only reactions taking place are the oxidation of thiocyanate to the inhibitor and the oxidation of the inhibitor by excess of hydrogen peroxide; (ii) that complete enzymic oxidation of thiocyanate proceeds according to the net reaction:

$$
\mathrm{SCN}^{-}+4 \mathrm{H}_{2} \mathrm{O}_{2} \rightarrow \mathrm{SO}_{4}{ }^{2-}+\mathrm{HOCN}+3 \mathrm{H}_{2} \mathrm{O}+\mathrm{H}^{+}
$$

with possible hydrolysis of cyanate to ammonia and bicarbonate; (iii) that the oxidation of the inhibitor is complete and does not give rise to any stable intermediate oxidation products when hydrogen peroxide is limiting. (iv) That on the initial addition of hydrogen peroxide, the only reaction occurring to a significant extent is the oxidation of thiocyanate to the inhibitor.

No evidence against these assumptions was found.

On the basis of the fourth assumption, the increase in $E_{235}$ per unit increase in hydrogen peroxide concentration for the reactions forming the inhibitor could be estimated from the tangent to the plot of extinction versus $\left[\mathrm{H}_{2} \mathrm{O}_{2}\right]$ as $\left[\mathrm{H}_{2} \mathrm{O}_{2}\right]$ approaches zero. Hence, assuming inhibitor formation to occur according to reactions (3), (4) and (8), and knowing the molar extinction coefficient of thiocyanate, the molar extinction coefficient for the inhibitor at $\mathrm{pH} 7.0$ could be determined. The molar extinction coefficients of the products of complete oxidation of the inhibitor (sulphate, cyanate, ammonia and bicarbonate) are all approximately zero at $\mathrm{pH}$ 7.0, therefore:

$$
E / \mathrm{d}=\epsilon_{\text {Inhibitor }}[\text { Inhibitor }]+\epsilon_{\mathrm{SCN}^{-}}\left[\mathrm{SCN}^{-}\right]
$$

Also, as all the added hydrogen peroxide was found experimentally to be utilized:

$$
\left[\mathrm{H}_{2} \mathrm{O}_{2}\right] \text { added }=n[\text { Inhibitor }]+4[\text { Products }]
$$

where $n=$ the no. of mol of hydrogen peroxide required to oxidize $1 \mathrm{~mol}$ of thiocyanate to the inhibitor, or:

$$
\begin{aligned}
& {\left[\mathrm{H}_{2} \mathrm{O}_{2}\right] \text { added }=n[\text { Inhibitor }]-} \\
& \quad \mathbf{4}\left(\left[\mathrm{SCN}^{-}\right]_{\text {initial }}-[\text { Inhibitor }]-\left[\mathrm{SCN}^{-}\right]_{\text {residual }}\right)
\end{aligned}
$$

where $\left[\mathrm{SCN}^{-}\right]_{\text {initial }}$ and $\left[\mathrm{SCN}^{-}\right]_{\text {residual }}$ are the thiocyanate concentrations before and after the addition of hydrogen peroxide respectively.

By solving eqns. (A) and (B) for [Inhibitor] and $\left[\mathrm{SCN}^{-}\right]_{\text {residual }}$ (all the other quantities being known), the concentrations of these compounds and of the products could be determined, assuming the inhibitor to be $\mathrm{OSCN}^{-}, \mathrm{O}_{2} \mathrm{SCN}^{-}$or $\mathrm{O}_{3} \mathrm{SCN}^{-}$at pH 7.0. These are listed in Table 6 for a solution containing thiocyanate and hydrogen peroxide,

Table 6. Calculated composition of a solution of the inhibitor prepared from equimolar amounts of thiocyanate and hydrogen peroxide

These figures were calculated from the results in Fig. 2(a) by the method outlined in the text. The initial $\mathrm{SCN}^{-}$and $\mathrm{H}_{2} \mathrm{O}_{2}$ concentrations were both $0.37 \mathrm{mM}$.

\begin{tabular}{ccccc} 
& \multicolumn{3}{c}{ Concn. (mM) } \\
\cline { 2 - 4 } Assumed identity of the inhibitor at $\mathrm{pH} 7.0$ & $\ldots$ & $\mathrm{O}_{3} \mathrm{SCN}^{-}$ & $\mathrm{O}_{2} \mathrm{SCN}^{-}$ & $\mathrm{OSCN}^{-}$ \\
$10^{3} \epsilon_{\text {Inhibitor }}\left(\mathrm{M}^{-1} \mathrm{~cm}^{-1}\right)$ & $\ldots$ & 3.87 & 2.86 & 1.84 \\
Inhibitor & $0.09_{2}$ & $0.13_{6}$ & $0.27_{5}$ \\
$\mathrm{SCN}^{-}$ & $0.25_{4}$ & $0.21_{0}$ & $0.07_{1}$ \\
$\mathrm{SO}_{4}{ }^{2-}=\left(\mathrm{OCN}^{-}+\mathrm{NH}_{4}{ }^{+}\right)$ & $0.02_{4}$ & $0.02_{4}$ & $0.02_{4}$
\end{tabular}


each at a concentration of $0.37 \mathrm{~mm}$. For $\mathrm{O}_{2} \mathrm{SCN}^{-}$ and $\mathrm{O}_{3} \mathrm{SCN}^{-}$, the amount of residual thiocyanate is just over half of the amount initially added, which is in agreement with the amount of thiocyanate estimated from the kinetic studies of the decomposition of the inhibitor to be residual in the inhibitor solution, while for $\mathrm{OSCN}^{-}$the amount is less than one fifth.

While the experimental results are consistent with the inhibitor being either $\mathrm{HO}_{2} \mathrm{SCN}$ or $\mathrm{HO}_{3} \mathrm{SCN}$, they do not permit a decision as to which of these it is. HOSCN, however, appears to be unlikely and there are no other likely oxidation products of thiocyanate the properties of which agree with those of the inhibitor.

We are indebted to Dr D. F. Kerr and Dr A. A. Humffray for their helpful discussion and criticism of some aspects of this investigation. This work was supported by grants from the Australian Dairy Industry Research Fund administered by the Australian Dairy Produce Board. D. McC. H. acknowledges the receipt of a Commonwealth Postgraduate Award.

\section{REFERENCES}

Bjerrum, N. \& Kirschner, A. (1918). K. danske Vidensk. Selsk. Skr. [8], V, no. 1; cited in Chem. Abstr. (1919), 13, 1057.

Bruce, R. B., Howard, J. W. \& Hanzal, R. F. (1955). Analyt. Chem. 27, 1346.

Chargaff, E., Levine, C. \& Green, C. (1948). J. bic' Chem. $175,67$.

Clem, W. H. \& Klebanoff, S. J. (1966). J. Bact. 91, 1848.

Hanssen, F. S. (1924). Br. J. exp. Path. 5, 271.

Jago, G: R. \& Morrison, M. (1962). Proc. Soc. exp. Biol. Med. 111, 585.

Jander, G., Grüttner, B. \& Scholz, G. (1947). Chem. Ber. 80, 279.

Johnson, L. D., Driedger, A. \& Marko, A. M. (1964). Can. J. Biochem. 42, 795.

Kerr, D. F. (1966). Ph.D. Thesis: Monash University, Melbourne, Australia.

Kitching, W., Smith, R. H. \& Wilson, I. R. (1962). Aust. J. Chem. 15, 211.
Klebanoff, S. J., Clem, W. H. \& Luebke, R. G. (1966). Biochim. biophys. Acta, 117, 63.

Klebanoff, S. J. \& Luebke, R. G. (1965). Proc. Soc. exp. Biol. Med. 118, 483.

Kolthoff, I. M. \& Lingane, J. J. (1935). J. Am. chem. Soc. 57, 2126.

Kolthoff, I. M. \& Sandell, E. B. (1952). Textbook of Quantitative Inorganic Analysis, 3rd ed., p. 574. New York: MacMillan Co.

Lecher, H., Wittwer, M. \& Speer, W. (1923). Ber. dt. chem. Ges. 56B, 1104.

Letonoff, T. V. \& Reinhold, J. G. (1936). J. biol. Chem. $114,147$.

Lewin, S. Z. \& Wagner, R.S. (1953).J.chem. Educ. 30, 445.

Mickelson, M. N. (1966). J. gen. Microbiol. 43, 31.

Morrison, M. \& Allen, P. Z. (1966). Science, N.Y., 152, 1626.

Morrison, M., Hamilton, H. B. \& Stotz, E. (1957). J. biol. Chem. 228, 767.

Morrison, M. \& Hultquist, D. E. (1963). J.biol.Chem.238, 2847.

Oram, J. D. \& Reiter, B. (1966a). Biochem. J. 100, 373.

Oram, J. D. \& Reiter, B. (1966b). Biochem. J. 100, 382.

Reiter, B., Pickering, A. \& Oram, J. D. (1963a). Rep. natn. Inst. Res. Dairy. p. 79.

Reiter, B., Pickering, A. \& Oram, J. D. (1964). In Microbial Inhibitors in Food, p. 297. Ed. by Molin, N. Stockholm: Almqvist and Wiksell.

Reiter, B., Pickering, A., Uram, J. D. \& Pope, G. S. (1963b). J.gen. Microbiol. 33, xii.

Seel, F. \& Müller, E. (1955). Chem. Ber. 88, 1747.

Slowey, R. R., Eidelman, S. \& Klebanoff, S. J. (1968). J. Bact. 96, 575.

Smith, R. H. \& Wilson, I. R. (1967). Aust. J. Chem. 20, 1353.

Söderbäck, E. (1919). Justus Liebigs Annln Chem. 419, 217.

Steele, W. F. \& Morrison, M. (1969). J. Bact. 97, 635.

Toennies, G. \& Kolb, J. J. (1951). Analyt. Chem. 23, 823.

Uri, N. (1947). Analyst, Lond., 72, 478.

Wilson, I. R. \& Harris, G. M. (1960). J. Am. chem. Soc. 82,4515 .

Wilson, I. R. \& Harris, G. M. (1961). J. Am. chem. Soc. 83, 286.

Wood, J. L. (1946). In Organic Reactions, vol. 3, p. 240.

Ed. by Adams, R. New York : John Wiley and Sons Inc.

Wright, R. C. \& Tramer, J. (1958). J. Dairy Res. 25, 104. 